University of Warwick institutional repository

This paper is made available online in accordance with

publisher policies. Please scroll down to view the document itself. Please refer to the repository record for this item and our policy information available from the repository home page for further information.

To see the final version of this paper please visit the publisher's website. Access to the published version may require a subscription.

Author(s): James Brassett, Lena Rethel, Matthew Watson Article Title: Introduction to the Political Economy of the Sub-prime Crisis in Britain: Constructing and Contesting Competence Year of publication: 2009 Link to published version: http://dx.doi.org/10.1111/j.1467-856X.2009.00376.x Publisher statement: The definitive version is available at www.blackwell-synergy.com 


\title{
Introduction to the Political Economy of the Subprime Crisis in Britain: Constructing and Contesting Competence
}

\author{
James Brassett, Lena Rethel and Matthew Watson
}

It is almost always inadvisable to try to second-guess the character of a General Election campaign before it begins in earnest. Yet, even in today's shadow-boxing phase in advance of the British General Election due to be called in 2010, a number of important campaign contours are already in evidence. It is one of the unwritten laws of British electoral politics that governments unravel - particularly those of a certain longevity - as events appear ever more to have spiralled out of their control. The task for the Brown Government in the upcoming General Election campaign is to try to convince voters that there is still life left within Labour despite its current travails with the credit crunch and British banks' self-imposed entrapment in the subprime crisis. Claim and counter-claim are likely to pass between the Government and the opposition parties as to where the blame lies for the current disarray of the banking sector, whose model of regulation is most responsible and who is best placed to ensure a successful clean-up operation. Whoever is perceived to have come out on top in this debate is likely to stand a very good chance of winning the election.

At stake is the ability of each party to project itself as the most competent in matters of macroeconomic management. Since the emergence of the distinctively New Labour phase of party politics in the mid-1990s, opinion poll data consistently showed that this matter was settled in the minds of voters in favour of Labour (Leggett 2005). Indeed, writing just before the eruption of the subprime crisis, Helen Thompson (2008) noted that New Labour had so successfully captured the competence agenda that many of its MPs had increasingly lost sight of Gordon Brown's role in forging that reputation; they mobilised instead behind alternative, purportedly more charismatic, candidates to succeed Tony Blair as Prime Minister. Brown's self-styled 'Iron Chancellor' persona, coupled with almost constant reiteration of performance indicators revealing an unbroken period of growth under his Chancellorship, helped to seize public recognition for being the party most trusted on the economy from its traditional association with the Conservatives (Keegan 2004). Yet, this historical reversal has itself latterly been reversed as the fallout from the subprime crisis spreads more widely around the British economy. Business failures, job losses, mortgage foreclosures and house repossessions mean the subprime crisis is already an integral feature of British electoral politics.

Our concern in this special section, however, is not to invite our participants to reflect on which of the main political parties most plausibly can claim macroeconomic competence in current circumstances. It is rather to ask them to fill in significant elements of the back-story which shapes the context in which the reputation for 
competence is today both claimed and challenged. It is clear that the whole notion is inflected with particular assumptions about what constitutes right behaviour within modern economies and about what constitutes right regulation of economic behaviour. One is thus struck with the intriguing possibility that each of the main political parties might approach voters in the upcoming General Election campaign with reform programmes in which competence is measured - somewhat oddly perhaps - by how swiftly they can recreate the generic socio-economic conditions out of which the subprime crisis arose in the first place. Problem-solving regulatory changes might already be coming on-stream in order to elicit rather greater oversight of banks' balance sheets and to guard against particularly egregious practices of credit creation. Yet, how effective, for example, can we expect the Turner Report recommendations for redesigning bank regulation to be in reconstituting actual bank behaviour when public ownership of the banks has not been used to assert public control of basic banking functions (see Financial Services Authority 2009)? The whole ideological structure of modern-day conceptions of macroeconomic competence is anathema to such control, which means that articulations of selfproclaimed competence are merely likely to offer more of the same as a solution to ongoing difficulties. The status quo ex ante thus looms large in current attempts at crisis resolution.

From our perspective, by contrast, the subprime crisis is a manifestation of the escalating contradictions of an increasingly financialised global capitalism. Such a model can only be reproduced if a leveraged structure of expanded debt obligations can be recycled through keeping asset bubbles afloat. The very nature of asset bubbles, though, is that they are founded upon a combination of economic and psychological foundations which itself proves to be tension-prone. Bubbles very rarely stay afloat beyond the short term. One of the tasks of future contextual research on the subprime crisis in Britain might therefore be to show how the dominant articulation of macroeconomic competence has become so closely tied to a bubble economy. The subprime crisis is something more endemic to the systemic logic of financialised capitalism than a merely temporary breakdown in an otherwise smooth allocation of credit. In short, the whole credit function in the British economy has been distorted by the incentive structure emergent from the dominant conception of macroeconomic competence.

Much of the early literature on the political economy of New Labour focused on its passivity in the face of the perceived need to demonstrate that it was worthy of eliciting the electorate's trust in its plans for government (e.g., Gamble 1996; Driver and Martell 1998). It emphasised the potential credibility of its programme in terms which were immediately recognisable as the endorsement of its Thatcherite inheritance (e.g., Heffernan 2001; Bauman 2007). The assertion of competence can be politically defined to suit just about any coherent set of policy proposals, but New Labour chose not to redefine the core features of the prevailing economic settlement. Its understanding of competence therefore matched that of its Conservative predecessor. To pass oneself off as credible in these terms meant to emphasise the benefits of light-touch regulation as a means of ensuring that credit creation took place within a structure of private property rights. To make the case for controlling the content of banks' decisions to activate credit flows was entirely antithetical to maintaining the impression of macroeconomic competence. This is the impression that all parties will likely attempt to convey in the upcoming General Election, but it 
is itself a highly contestable aspect of the way in which the political economy of Thatcherism informed the governing programme of New Labour.

In their own manner, the authors of each of the papers contained in this special section seek to probe possible areas of contestation in the structure of competence out of which the subprime crisis arose. None do so directly, because this was not the theme of the workshop for which the initial drafts of the papers were first solicited. ${ }^{1}$ The workshop focused on the political economy of the response to the subprime crisis, envisaging that the response would itself tell us important things about the causes of the crisis. We asked our participants to engage critically with the response currently enacted by the Brown Government so that they might help us to learn more about the understanding of 'normal finance' which is inscribed into the response. In general, that understanding will lead to one of two basic explanations of the causes of the crisis. Is the crisis merely the result of a temporary malfunctioning of an otherwise unproblematic credit system, as manifested in the anomalous allocation of credit to increasingly exotic mortgage products? Or is the crisis evidence of something much more fundamental than that? Is it an essential feature of a process of financialisation which strives for societal incorporation into its economic structure via the pricing trajectory of asset bubbles?

The policy response which seeks the immediate restoration of 'normal' allocation functions in the former scenario serves only to reproduce the original problem in the latter. There is much at issue, then, in beginning to unpack the nature of the bank bailouts undertaken by the Brown Government. The bailouts reflect not only a particular understanding of what has gone wrong and how it can be put right, but also a particular commentary on the political interests which were embedded in the status quo ex ante and which will receive privileged treatment in any attempt to restore that status quo. The headlines surrounding the bailouts have typically focused on the sheer volume of public money being made available to provide the banks with a route to renewed balance sheet health, as well as on the repercussions for future policy of paying back that debt. But a rather different story emerges when the focus turns to the broader political vision which the bailouts serve to sustain and the political interests which are constitutive of that vision.

The first three papers in the following collection address themselves explicitly to this issue. In that respect, they also provide interesting accounts of the potential meaning of the competence which will be both asserted and denied in the upcoming General Election campaign. (1) In his paper, Colin Crouch looks broadly at the governing strategy which has emerged from the eclipse of traditional forms of Keynesianism in Britain since the 1970s to conclude that this has amounted to 'privatised Keynesianism'. The subprime crisis places the sustainability of such a strategy in doubt, because it is based on individualised financial habits which can be maintained only in the presence of easy bank credit. However, the banking sector distress which is the most obvious immediate effect of the subprime crisis has led to a significant tightening of credit and, as a result, to a greater political imperative for individuals to rein in their existing debt leverage. (2) Alan Finlayson takes a similar line on the link between the subprime crisis and potential fractures in the governing strategy currently underpinning the British economy, but he focuses his analysis at a different level. Whereas Crouch is interested in the broad macroeconomic dimension of that strategy, Finlayson concentrates instead on understanding how the macroeconomic imperatives 
filter down into the personal economic subjectivities of a newly financialised citizenry. The housing market has recently provided the primary means of enabling the future welfare aspirations of asset-owning citizens to be fulfilled, but the precredit crunch structure of house prices looks as though it will be a clear casualty of the subprime crisis. (3) Matthew Watson works in between these two levels of analysis, showing that the politics of the bank bailouts might well serve to recreate Crouch's privatised Keynesianism, but that they do so primarily through the articulation of a middle-class politics designed to protect existing wealth accumulated on the housing market. Watson charts the way in which a middle-class moral panic of the 'responsible mortgage borrower' has been used to justify the presentation of a politically contestable blank cheque of public money to help banks repair their balance sheets and reactivate the credit functions of privatised Keynesianism.

The two papers with which the collection concludes focus on how this governing strategy - and its associated understanding of competence - impacts upon the management of the British economy. (4) In their paper, Andrew Leyshon and Shaun French study one manifestation of the exigencies of a credit system in which allocation decisions impact pro-cyclically in order to reinforce dominant asset price trajectories. They provide a genealogy of the rise and fall of the buy-to-let sector within the British housing market, conceptualising buy-to-let mortgage lending as a 'socio-technology of financialisation' which exposes certain segments of a financialised citizenry to the full force of macroeconomic shocks. The distribution of this exposure has a spatial component insofar as it particularly affects certain localised housing markets, but it also has a social component in terms of what strata of society it affects the most. (5) Colin Hay shows how the creation of such spatial and social vulnerabilities was functional to the growth experience of the British economy under New Labour. He consequently demonstrates that the macroeconomic dimension of the underlying governing strategy passes through the unequal financialisation of the citizenry. This dynamic is itself built upon a core tension which has remained relatively uncontroversial during the period in which house prices surged ahead but is likely to become more central to political debates in the context of falling prices. He suggests that the governing strategy has been based on a discursive bifurcation of different types of inflation as either 'good' or 'bad', with the good applying to the housing market and the bad to consumer prices in general. This has had the effect of moralising recent bubble dynamics in house prices, thus securing them against political interventions designed to lessen such steep increases.

\section{Notes}

1 The workshop was held at the University of Warwick on 18/19 September 2008. We gratefully acknowledge financial assistance from the host institution, the Economic and Social Research Council (project number RES-000-22-2198), GARNET - the EU Network of Excellence on Global Governance, Regionalisation and Regulation, and the Political Studies Association of the UK. More information about the workshop appears at http://www2.warwick.ac.uk/fac/soc/pais/research/ipe/subprime/, including links to the recordings of all the academic papers. 


\section{References}

Bauman, Zygmunt (2007) 'Britain After Blair, or Thatcherism Consolidated', in Gerry Hassan (ed.) After Blair: Politics After the New Labour Decade (London: Lawrence and Wishart), 60-74.

Driver, Stephen and Martell, Luke (1998) New Labour: Politics After Thatcherism (Cambridge: Polity Press).

Financial Services Authority (2009) The Turner Review: A Regulatory Response to the Global Banking Crisis (London: Financial Services Authority).

Gamble, Andrew (1996) 'The Legacy of Thatcherism', in Mark Perryman (ed.) The Blair Agenda (London: Lawrence and Wishart), 18-38.

Heffernan, Richard (2001) New Labour and Thatcherism: Political Change in Britain, revised paperback edition (Basingstoke: Palgrave Macmillan).

Keegan, William (2004) The Prudence of Mr Gordon Brown (Chichester: John Wiley and Sons).

Leggett, Will (2005) After New Labour: Social Theory and Centre Left Politics (Basingstoke: Palgrave Macmillan).

Thompson, Helen (2008) Might, Right, Prosperity and Content: Representative Democracy and the International Economy, 1919-2001 (Manchester: Manchester University Press). 